\title{
Cleaning up Cosmos: Satellite Debris, Radioactive Risk, and the Politics of Knowledge in Operation Morning Light
}

\author{
Ellen Power \\ University of Toronto
}

Arn Keeling

Memorial University

\begin{abstract}
In the early morning of January 24, 1978, the nuclear-powered Soviet satellite Cosmos 954 crashed on the barrens of the Northwest Territories, Canada. The crash dispersed radioactive debris across the region, including over multiple communities. A close reading of the archival record of the military-led clean up operation that followed, known as Operation Morning Light, shows how the debris recovery effort was shaped by government understandings of the northern environment as mediated through authoritative science and technology. This authority was to be challenged from the very beginning of Operation Morning Light. Constant technological failures under northern environmental conditions only increased the uncertainty already inherent in determining radioactive risk. Communication of this risk to concerned northerners was further complicated by language barriers in the predominantly Indigenous communities affected. For many northern residents, the uncertainties surrounding radiation detection and mistrust of government communication efforts fueled concerns about contamination and the effectiveness of debris recovery. Though an obscure episode for many Canadians today, the Cosmos crash and recovery intersects with important themes in northern history, including the politics of knowledge and authority in the Cold War North.
\end{abstract}

The Northern Review 48 (2018): 81-109

Published by Yukon College, Whitehorse, Canada 
On January 28, 1978, amateur explorer John Mordhurst was overwintering in a cabin near Warden's Grove, a small copse of trees on the Thelon River in the Northwest Territories. He and five other young men were on a journey of "personal growth" to retrace the footsteps of Englishman Jack Hornby, an Arctic adventurer who died in the area in $1927 .{ }^{1}$ On a short trip away from their cabin, Mordhurst and one of his friends noticed what looked like a piece of an aircraft, lying in a crater in the snow. They examined the piece of twisted metal as they "joked about it probably being a Russian satellite" that had fallen from the sky. ${ }^{2}$

Upon their return to base camp, the two were startled to learn of recent radio reports that the Canadian military was searching for a satellite that had crashed in the area only a few days before. The explorers reported their find by radio to Yellowknife, roughly 500 kilometres southeast of Warden's Grove (Figure 1). Within twenty-four hours, military aircraft had arrived at the group's campsite to take charge. Teams sporting protective gear and wielding radiation-detecting equipment were quickly shown to the crater. They gave Mordhurst and his friend little information as the men were evacuated to Edmonton for decontamination and radiation testing. The two adventurers had indeed-as they had joked-found a piece of a Russian satellite. This nuclear-powered satellite (known as Cosmos 954) had burned up in a rapid re-entry above Canada just four days earlier, spewing radioactive debris across hundreds of square kilometres of the Canadian North.

The incident at Warden's Grove is only a side note in the story of Operation Morning Light, the massive joint Canadian-American mission launched to clean up the radiation left by Cosmos 954. The nuclear-powered Soviet satellite malfunctioned in orbit, resulting in its unexpected re-entry above Canada in the early hours of January 24, 1978. As the satellite's uranium reactor core disintegrated on its descent, Cosmos 954 left a trail of potentially dangerous debris in its wake. This material ranged from several large fragments, like the one found by Mordhurst, to a multitude of tiny radioactive particles detectable only by specialized machines (Figure 2). 


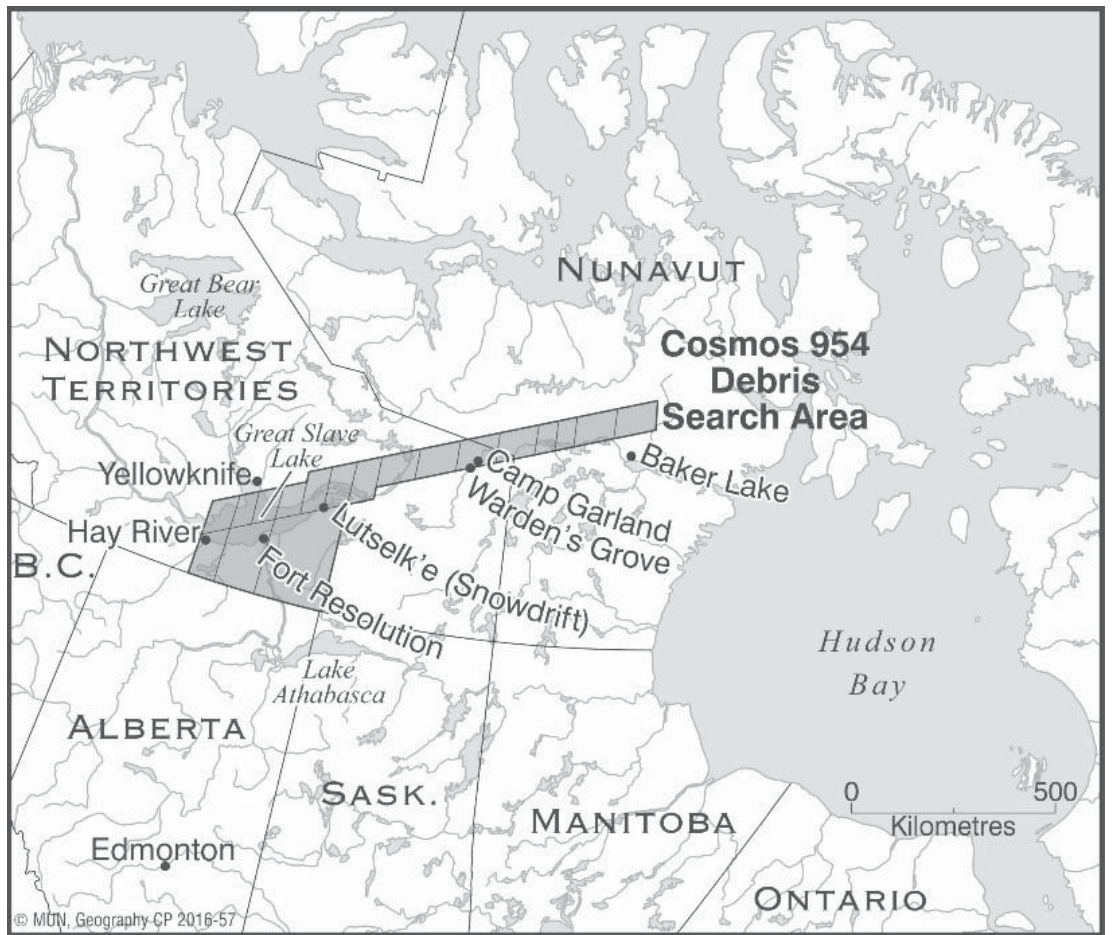

Figure I.The Cosmos 954 debris field as covered by Operation Morning Light. The long upper arm represents the initial search area based on the satellite trajectory. This search area was later expanded south towards Alberta and Saskatchewan. Map by Charlie Conway.

The subsequent military-led effort to remove this widespread radioactive contamination was a laborious process. It involved hundreds of ground personnel and cost the Canadian government nearly $\$ 14$ million. $^{3}$ Dubbed Operation Morning Light, the search for satellite debris lasted about eight months and encompassed a vast, remote swath of northern Canada. The operation required both extensive aerial surveys and the use of ground search teams, as well as the establishment of a temporary military base near the Thelon River. In April 1981 Soviet and Canadian diplomats signed a compensation settlement of $\$ 3$ million to be paid from the USSR to Canada. ${ }^{4}$ After that time, Operation Morning Light disappeared quickly from the media, though not necessarily from the memories of northerners, who had experienced the impacts of the crash and recovery mission firsthand. 


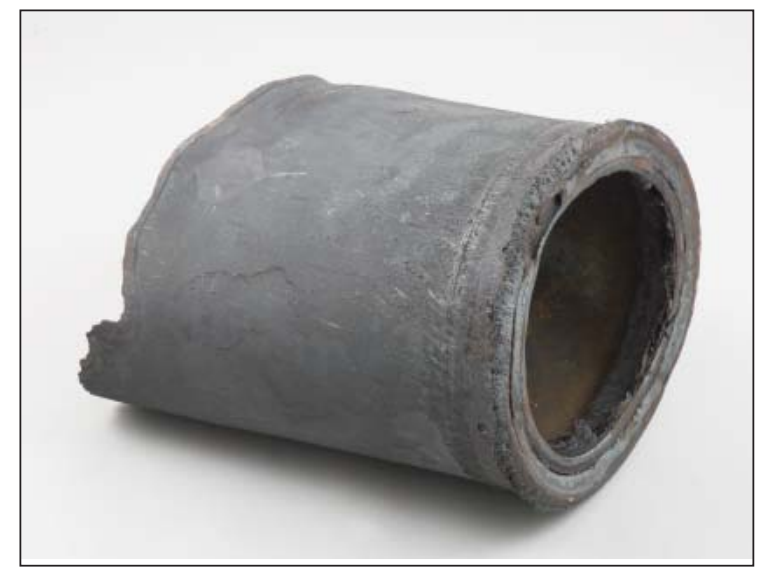

Figure 2.The "stovepipe," as it was nicknamed, was one of the largest pieces of satellite debris found (measuring $70 \mathrm{~cm}$ in length and $30 \mathrm{~cm}$ in diameter). This non-radioactive fragment was discovered by a chance aerial sighting; the majority of the Cosmos 954 debris fell as radioactive particles approximately the size of pepper grains, which were impossible to detect without specialized equipment. Photo used with permission of Northwest Territories Archives.

The Cosmos 954 episode flashed into visibility the connection of northern Canada, seemingly distant from Cold War geopolitics, with the geographies of militarization. Of course, by the late 1970s the North had a long history of such entanglements-whether as a theatre of military operations during the Second World War, the site of uranium mining for Allied nuclear weapons development, or the construction in the 1950s of the Distant Early Warning (DEW) Line radar system. ${ }^{5}$ Northern environments and people were directly affected by these military-industrial activities: through pollution from uranium extraction and transport, for instance, or the legacies of construction and chemical wastes left at DEW Line stations, both of which in recent years have been the subject of local concern, scholarly analysis, and government clean up efforts. ${ }^{6}$ The case of Cosmos and Operation Morning Light, however, remains relatively obscure, perhaps because of the seemingly accidental and ephemeral nature of the crash and cleanup. ${ }^{7}$

A close reading of Operation Morning Light, based on the archival record (largely consisting of government documents) and the official historical account (written by a member of the Morning Light ground team), suggests important continuities and resonances with these earlier encounters between military actors and northern environments and people. 
During the recovery operation, official news releases and media reports often portrayed the region as "wastelands, [far] away from any settlement." In fact, there were thousands of people, principally Indigenous, who lived, travelled, and harvested within the debris field. These northerners had little say in how Operation Morning Light was conducted by government and military personnel. They struggled to interpret the risk of nuclear contamination in the context of both government science and their own place-specific understandings of the landscape. Many felt uninformed about the risks of radiation and unheard in their communications with official representatives, who seemed to dismiss or ignore their concerns.

For their part, the military commanders and scientists who coordinated Operation Morning Light did not initially realize the scope of the contamination from Cosmos 954; nor did they truly comprehend the size and environmental conditions of the northern landscape. They undertook the recovery mission under the assumption that southern technology and standard operating procedures would function equally well in a northern environment. Under the "normal working conditions" of southern environments, Operation Morning Light may have seemed like a straightforward recovery mission (with the help of specialized aircraft, radiation detectors, and maps of the entire region). In reality, "normal" working conditions as established in southern laboratories and landscapes were nothing like those of the Northwest Territories in winter. Canadian and American recovery teams struggled to carry out inefficient search operations with inappropriate gear that often malfunctioned. These technological and logistical challenges resulted in official uncertainty about contamination levels, even as search results were used to refute community concerns. Reinforced by the difference between outsider and northern ways of viewing the landscape, the written narratives of Operation Morning Light that emerged often discounted northerners' perceptions of risk and their lingering concerns about Cosmos radiation in the environment.

These encounters amongst people, organizations, technologies, and environments register familiar themes in northern history. The North, argues historian Ken Coates, has consistently been defined by the "conceptual frameworks and intellectual paradigms" of southerners, who interpreted Canada's North through the eyes of outsiders. ${ }^{9}$ Like the young explorers at Warden's Grove, many southern Canadians at the time of the Cosmos 954 incident still understood the Canadian North 
through the southern tropes of exploration and danger. Historian Shelagh Grant has described this as the "Arctic Wilderness Myth": the persistent conceptualization of the North as a beautiful but forbidding (and largely unoccupied) wilderness. This imagined North is a barren landscape in which the strong are challenged to survive and in which very few people would choose to live permanently. ${ }^{10}$ Grant and others trace the roots of this imagined geography to nineteenth century conceptualizations of the North, but similar frontier conceptualizations persisted well into the Cold War era-though altered in the face of postwar military, industrial, and technological developments.

Wartime and Cold War military development, in particular, was often portrayed as the conquest of an adversarial wilderness in order to protect the nation. "Overcoming a treacherous environment," write geographer Matthew Farish and historian P. Whitney Lackenbauer, "became a typical narrative for media stories on [northern military development], stories that similarly highlighted the successful application of modern solutions to treacherous terrain." 11 Their studies of military installations (like the DEW Line) and urban developments (like Iqaluit and Inuvik) emphasize the "high-modernist" conquest of hostile nature, reflecting the attitude that "the distinctiveness of northern landscapes could be subdued or even overcome" thanks to innovations in logistics, technology, and scientific knowledge. ${ }^{12}$ From this perspective, the North was both laboratory and proving ground, where southern ideas and technology could be tested in more extreme environments. In their interactions with Arctic environments, Farish has shown in the context of American military science in Alaska, military experts "produced and promoted certain forms of knowledge about the north, knowledge that in turn contributed to particular definitions" of northern lands and peoples. ${ }^{13}$

These attitudes extended to the realms of state-sponsored science and social policy in Canada. The government forces behind postwar development imagined a northern environment that could be reshaped by southern scientific knowledge and technology, rather than an environment that would require southerners to adapt. Historian of science Stephen Bocking calls this "mobile science": the ways in which scientists downplayed the influence of place or regional variation in favour of the idea that knowledges and technologies could be applied anywhere regardless of where they originated. ${ }^{14}$ Bocking argues that the growing 
postwar emphasis on interpreting northern landscapes through scientific techniques "exemplified a new kind of relationship between Canadians and their environment, particularly in northern Canada: one mediated by ... expertise." ${ }^{15}$ In doing so, experts constructed the North as a standardized laboratory setting, validating the scientific authority of their knowledge and technology over local ways of understanding the landscape. ${ }^{16}$ The rule of experts extended to the social and economic realms as well, where government officials sanctioned "experimental" approaches to northern development, including mineral exploitation, Indigenous employment, and (notoriously) the relocation of Indigenous communities. ${ }^{17}$

The Cosmos recovery and decontamination operation resonates with these themes of the politics of knowledge and authority in the North. Experts involved with Operation Morning Light regarded the environment through the lens of "universal" knowledge and technology, rather than relying on place-specific knowledge. This tendency was reinforced in the case of Cosmos 954, whose radioactive debris could only be detected through specialized sensing equipment. The ability of these experts to "produce and promote certain forms of knowledge" about radioactive debris in the northern environment relied on establishing what historian Michelle Murphy calls a "regime of perceptibility": the powerladen configuration of cultural and technological things and relations that make certain phenomena or effects visible (or "real") while dismissing or marginalizing others. ${ }^{18}$ Drawing on Murphy's work, Stephen Bocking usefully applies this concept to the contested development of knowledge surrounding the distribution and effects of persistent organic pollutants (POPs) in the Canadian North in the 1980s. ${ }^{19}$ Similar to the issue of POPs, the particular regime of perceptibility at work in the Cosmos case tended to privilege technoscientific determinations of exposure and risk over local and vernacular understandings. The power to do so, we argue, reflected not only the context of Cold War relations among Indigenous peoples and southern military, government, and scientific actors, but also the elusive material qualities of mostly microscopic radioactive debris spread over a massive region, largely imperceptible to the human sensorium, whose particular somatic effects remained uncertain.

However, the elevation of scientific expertise over first-hand experience of the environment rarely prevented local people from interpreting contaminants like radiation through their own vernacular 
ways of knowing. The divergent perceptions of risk and toxicity by scientists and laypeople is a well-established theme in environmental and discard (waste) studies. ${ }^{20}$ In a northern Indigenous context, geographer Martina Tyrrell has described how Inuit in Arviat, Nunavut, interpret radiation risk in country food through the physical condition of an animal, even though this method does not necessarily correlate with official scientific opinion. ${ }^{21}$ Similarly, anthropologist Joslyn Cassady has discussed how Inupiaq communities in Alaska interpreted the undetectable risk of radiation waste hazards within frameworks of both traditional ecological knowledge and technical expertise. ${ }^{22}$ Both these studies are particularly salient, as they discuss scenarios in which radiation was acknowledged to be present in the environment by scientists and government officials, but where the effects of exposure were uncertain or contested. Similarly, during Operation Morning Light, uncertainty about the extent and effects of known contamination, filtered through miscommunication and a distrust of government authorities, led community members to question official accounts of radiation risks from exposure to Cosmos debris.

The story of Operation Morning Light began in December 1977 when the Soviet Union notified the United States that one of its satellites was in a decaying orbit and was likely to fall somewhere over North America. This nuclear-powered naval surveillance satellite was Cosmos 954. ${ }^{23}$ After re-entering the atmosphere above Canada's West Coast at approximately 5:00 a.m. MST on January 24, 1978, Cosmos 954 burned up over the Northwest Territories. Surprised onlookers across the Great Slave Lake region witnessed the light of the flaming satellite as it streaked through the early morning sky. As it disintegrated, radioactive fragments of Cosmos 954 were strewn across an estimated 124,000 square kilometres of the Northwest Territories between Hay River and Baker Lake (Figure 1). ${ }^{24}$ Radioactive particulate released in the upper atmosphere dispersed even further with some airborne particles found in northern Saskatchewan and Alberta. Nine communities were contaminated by particles of Cosmos debris, with Fort Smith, Hay River, Pine Point, Fort Resolution, and Lutselk'e (then known as Snowdrift), most notably affected..$^{25}$ A large influx of military search teams soon overwhelmed these communities, as well as Yellowknife and Baker Lake, which became the operational centres of Operation Morning Light. 
After the re-entry was confirmed, Canada immediately accepted an offer of support from the United States. (The Soviet offer of assistance that followed was turned down. ${ }^{26}$ ) Unlike the Canadian government, the US Department of Energy already had a professional task force of scientists and military personnel equipped to handle incidents of nuclear contamination. The Nuclear Emergency Search Team (NEST) had been put on standby alert as soon as it became apparent that Cosmos 954 would re-enter over North America. ${ }^{27}$ In contrast, the Canadian equivalent, the Nuclear Accident Support Team (NAST), consisted of part-time volunteers from the Canadian Forces who had been given some additional training on nuclear disasters. NAST members had few resources compared to their American counterparts. They also had less time to prepare for a clean up operation: they were informed of Cosmos 954 only four days before the satellite's re-entry. ${ }^{28}$

Though a joint Canadian-American operation, Col. David F. Garland of Canadian Forces Base (CFB) Edmonton assumed command of the Operation Morning Light search teams. ${ }^{29}$ The majority of the initial search and recovery operations were based out of the Inuit hamlet of Baker Lake (now part of Nunavut). However, Baker Lake soon proved insufficient for military purposes. The town did not have the utilities for a large-scale military operation, lacking even a private telephone line for military teams. ${ }^{30}$ In addition, search crews faced long flights in freezing conditions from Baker Lake to the areas where debris had already been found. Officials decided to construct a military landing strip on the newlynamed Cosmos Lake. This temporary base, located near Warden's Grove where Mordhurst and his companion discovered the large piece of satellite debris, was called Camp Garland. ${ }^{31}$

Operation Morning Light took place in two separate phases. The Phase I cleanup lasted from late January until April, when spring melt conditions began to hinder searches. Phase I consisted of survey flights in a grid pattern over the suspected debris field, with radiation-detecting equipment contributed by the American NEST. As illustrated in Figure 1 , the total search area covered just over 75,640 square kilometres, mainly in the Northwest Territories. ${ }^{32}$ Radioactive "hits" were picked up by the aircraft's gamma ray spectrometer, with the location of each hit recorded by the helicopter crew. Teams of American and Canadian personnel were then dispatched to investigate these locations on the ground. The 
teams identified Cosmos debris using handheld Geiger counters and scintillators. The recovered particles were sent to the Whiteshell Nuclear Research Establishment labs in Pinawa, Manitoba-run by Atomic Energy of Canada, Limited (AECL) an agency affiliated with the Canadian government. The reactor core of the satellite was never found; it was presumed to have disintegrated during re-entry. ${ }^{33}$ In early March 1978, American crews began to be phased out. The Phase I cleanup ended in April during the melt period.

Around the end of Phase I, the Atomic Energy Control Board (AECB, now the Canadian Nuclear Safety Commission) joined the detection and recovery effort. Principally a regulatory agency responsible for the uranium and nuclear industries, the AECB also began holding public meetings with concerned communities in the Northwest Territories as well as in northern Saskatchewan and Alberta. The goal of the meetings was to explain Operation Morning Light to residents while reassuring them that the Cosmos 954 debris posed no lasting risk. Public meetings continued into the period of the Phase II cleanup, which lasted from July to October 1978. The Phase II cleanup was completely turned over to the $\mathrm{AECB}$, which contracted the recovery work out to a private company. ${ }^{34}$ This part of the cleanup consisted primarily of on-the-ground surveys using handheld detecting equipment. The chief goal was to remove any remaining radioactive debris from within affected communities. ${ }^{35}$ The Phase II cleanup team recovered thousands of debris particles during this time-workers recovered over sixty radioactive particles from a single backyard in Fort Smith. ${ }^{36}$ Active recovery of contamination ended with Phase II in October. Any undiscovered particles of debris were expected to fade quickly into the background radiation of the local environment. ${ }^{37}$ Ultimately, despite their efforts, search teams located and cleaned up only an estimated $0.1 \%$ of the total radioactive material from Cosmos 954.The remainder was deemed to be of low risk to people or the environment, as the particles were widely dispersed and steadily weakening in radioactivity. ${ }^{38}$

For all the advanced military organization and expertise mobilized, Operation Morning Light was plagued with technological and logistical difficulties from the very start. The military officials who rushed to send recovery teams to the Northwest Territories quickly realized the problems with running a "normal" military operation in what was to them an unfamiliar and often harsh environment. In the mission's final report, 
the struggle of Morning Light personnel simply to cope with a frigid northern winter (with little advance preparation) comes across as the real achievement of the whole operation, with the clean up of radioactive debris seeming almost secondary. ${ }^{39}$ The Canadian government's official narrative of Operation Morning Light is a story of the northern landscape as approached by outsiders, for whom radiation is just another minor risk in an already hostile environment.

Government accounts may present Operation Morning Light crews as conquering the North, but in reality, the early days were shaped by considerable improvisation and adaptation to the northern landscape rather than control of it. Much of the official planning process did not take into account the location of the debris field: a remote region where the little infrastructure that existed was separated by vast distances. The initial base of field operations, Baker Lake, was overrun by military teams. This rapid population increase in a community of approximately 1,000 not only overwhelmed the local infrastructure, but also the hamlet's predominantly Inuit population who were given only piecemeal explanations of what was going on. The difficulty of communicating with command centres in faraway Edmonton and Ottawa meant that the base of operations in Baker Lake faced chronic equipment shortages. Crews were often sent to buy basic necessities at the local Hudson's Bay store. ${ }^{40}$ In the first weeks of the search, the teams even lacked proper lead-lined canisters to safely contain the radioactive debris; instead, any fragments discovered were placed in water-filled cans. ${ }^{41}$ When lead-lined canisters did become available, there were always fewer than the recovery mission demanded. One piece of located debris was found to be so radioactive that the existing canisters could not contain it; this fragment remained on the ground until a suitable container could be designed and sent up from the University of Alberta. ${ }^{42}$

The extreme Arctic climate was the biggest barrier in preventing the military from carrying out standard operational procedures. Much of the team's equipment was simply not designed to cope with the conditions of a northern winter. After only a few trips, it became apparent that the $\mathrm{CH}-$ 147 helicopters being used to transport survey teams from Baker Lake to the search area around Warden's Grove were particularly susceptible to the winter weather conditions. The helicopters were parked outside in temperatures that dipped below $-40^{\circ} \mathrm{C}$. When left unheated for too long, the helicopters would fail to restart. 
The first major failure occurred barely ten days into the operation. Seventeen team members on a scouting trip to the newly-named Cosmos Lake were stranded overnight in a blizzard when their helicopter engine was too cold to start for the return trip to Baker Lake. Some of the stranded crew members, especially the Americans, had no prior experience of winters in the Canadian North. C.A. Morrison's history of Operation Morning Light recounts the crew's fearful reactions to a situation that seemed to validate all their pre-existing ideas of the North:

[After trying to start the engine for half an hour,] it was completely dark; and they had left the door opened ... so that everyone inside [the helicopter] was just frozen solid; and we were faced then with a shutdown with about half the people virtually incapacitated-just in a state of coma to shock. At that point, some of the Americans, who were out of Las Vegas ... were panicky at the thought of just being left there ... We got the stove going and we moved those people who were virtually useless to us at that point in [to a tent $]. . .43$

For the American crew members, the North was still the frigid, hostile wasteland of explorer narratives, the "voyage into the unknown" that gave Morrison's history of Operation Morning Light its title. The story of their survival against the elements-thanks to the quick thinking and resourcefulness of their Canadian comrades-even seems to echo the heroic narratives of Arctic adventurers.

The CH-147 helicopters were eventually moved to heated hangars in Yellowknife. ${ }^{44}$ Despite their flaws, these helicopters continued to be used for the remainder of Operation Morning Light's Phase I cleanup. ${ }^{45}$ The Operation Morning Light final report emphasized that "only the hard work and determination of 450 Squadron technicians and flight engineers kept the helicopters operating," a statement that implies success was due more to the military's perseverance, than adaptation to the northern winter conditions. $^{46}$

Freezing temperatures also impacted the equipment used on ground searches. Most of the satellite debris had fallen as nearly-invisible radioactive particles, which ground search teams had to locate using portable Geiger counters and scintillators (Figure 2). The severe cold 
quickly drained the batteries of these devices "to such an extent," according to one report, "that it was essential to keep batteries warm by either holding the whole instrument inside one's parka between uses, or removing the batteries and keeping them in a warm pocket until required again." ${ }^{\prime 7}$ Ground search teams also encountered difficulties when collecting ice samples, as the diesel-powered drill would not function in the freezing conditions. While surveying the frozen Thelon River near Warden's Grove, a search team out of Baker Lake gave up on the drill and "reverted to" local Inuit ice chisels to break the ice for testing. ${ }^{48}$

The technical failures that plagued Operation Morning Light are particularly evident in the military's aerial radiation surveys during the Phase I cleanup. Planes equipped with radiation-sensing equipment flew in a grid pattern over the suspected re-entry path of Cosmos 954 to determine the extent of the debris field (Figure 1). Concerned about portraying the recovery as a "totally Canadian-controlled operation," Operation Morning Light officials insisted American radiation detection equipment be loaded onto Canadian planes, which delayed the launch of the operation. ${ }^{49}$ When functioning properly, the radiation detectors picked up points of high radiation on the ground below. These points were later examined by a ground team to determine if the radiation was indicative of satellite debris.

However, the sensing equipment used in the airplanes only functioned efficiently over frozen bodies of water. When flying over land, the background radiation (particularly that from natural mineral deposits) often caused false readings. The equipment was obviously poorly-designed for the particularities of surveying the Northwest Territories; however, some of the equipment may not have been designed for any environment outside of the lab in which it was created. In one early incident, an anomaly (indicating a spot of radiation) appeared on the record tape of an aircraft radiation detector. The crew, unfamiliar with the equipment, was unable to determine when and where this anomaly had been recorded. According to Morrison, this incident was "only the second operational use of [the] detector and neither operator had any experience in its use under field conditions." ${ }^{50}$ In other words, neither the accuracy of the equipment nor the operator could be proved-reinforcing the impression that the recovery mission was "largely an experiment" for the Canadian Forces, as 
they tested new technology and field procedures in their efforts to operate efficiently in an extreme environment. ${ }^{51}$

The use of grid-style aerial surveys reflected earlier twentieth-century institutional ambitions described by historian Marionne Cronin: to map northern landscapes using "efficiency, robustness, speed, and utility over rigorous accuracy [in order] to obtain greater control over ... the Canadian North." 52 Stephen Bocking similarly emphasizes how the incorporation of aerial surveying into geological exploration, wildlife surveys, and other scientific applications after the Second World War reinforced the authority of scientific expertise in rendering northern nature "legible" to southern authorities. ${ }^{53}$ During Operation Morning Light, however, military personnel frequently found that the pre-existing aerial maps of the Northwest Territories were of little use to flight crews. Not all the areas within the Cosmos debris field had even been mapped; the maps that did exist were sometimes at an inappropriate scale for the use required. The winter conditions often rendered map-based navigation useless; crews were unable to rely on visual landmarks due to snow cover and poor visibility. On several occasions, these navigational difficulties led the helicopter pilots over a hundred miles off course. ${ }^{54}$ The public information team for Operation Morning Light stressed the magnitude of the challenges faced by aerial search teams, asking "How does one go about finding small, minute pieces and radioactive particles in an area the size of Switzerland which had nil navigation aids, compasses are uncertain and the chill factor is in the 40-85 below zero celsius range?" ${ }^{55}$ What might have been possible with aerial surveillance in summer was unreliable in snowy conditions and extreme cold temperatures. The technique of aerial surveying aimed to reduce a huge expanse of territory to lines on a map; this artificial construct had little in common with the real world conditions both flight crews and ground search teams would face in Operation Morning Light.

Search crews also struggled with the wide variability in accuracy among the different portable instruments being used. When the Americansupplied detecting equipment was functioning at optimal levels, the upto-date equipment was sensitive even to low levels of radiation. In contrast, the Canadian devices were "antiquated and coarse-reading." Dosimeters sometimes registered high doses of radiation when they did not exist and the handheld devices used for surveying sometimes failed to pick up on low level radiation at all. ${ }^{56}$ The most problematic episode occurred on 
January 30, when crews were completing their first surveys of communities. The Canadian detecting devices used were not as sensitive as some of the American models. As a result, early searches of the Dene community of Lutselk'e (Snowdrift) showed no radiation at all and the community was declared clear of radioactive particles. The initial declaration proved uncomfortably hasty, after subsequent crews returned with more effective equipment and did pick up radioactive readings. Indeed, Lutselk'e turned out to be one of the most densely contaminated settlements in the Cosmos 954 debris field. Recovery teams eventually removed approximately 100 radioactive particles from the community during the Phase I search. ${ }^{57}$ This sort of official misstep would not inspire trust among affected communities, only providing fuel for community groups in the area who felt they were being misinformed.

In addition to the failure of official mapping on the operational level, maps representing the debris field were constantly being revised to reflect the changing search field. Government officials categorized the debris field into various zones of contamination, which allowed for easier management of a task force and methodical search of the area. But over the course of Operation Morning Light, wind-blown radioactive particles were detected further to the south, near the borders of Alberta and Saskatchewan. The map then had to be modified to include areas that had previously not been of concern. Some areas even further south in northeastern Alberta and northwestern Saskatchewan were suspected to contain some fine radioactive debris, but levels were estimated to be so low that no clean-up operations were performed in the area. ${ }^{58}$ Since the debris in these regions was deemed of little risk, final maps of the debris field did not include these areas. However, residents in affected areas of Saskatchewan and Alberta were unconvinced that they were safe from nuclear contamination simply because they were left off official maps. The band council from Fond du Lac (on Lake Athabasca) sent a letter through a local bureaucrat to the AECB in March, asking for over one hundred Geiger counters so that local residents could determine local radiation levels for themselves. ${ }^{59}$ A map portraying strict boundaries between contaminated and uncontaminated zones (including following the arbitrary territorial border) failed to acknowledge the uneven distribution of radiation within the contaminated areas, or to represent the uncertainty that many northerners felt. 
Cartographic representations of the region portrayed the North purely as a physical space over which a recovery mission was taking place. In fact, there were several communities within affected regions, most with significant Indigenous populations. Officials did not initially inform residents of these affected communities about the start of the recovery mission; some, like the people of Lutselke, had no explanation about the recovery operation until after military teams in protective gear appeared in their community to search for radioactivity. ${ }^{60}$ Of all the people living within the debris field, the reactions of Dene and Inuit were most notably absent in government reports. One of the reasons for this was the language barrier between English-speaking officials and the residents of predominantly Indigenous communities, where for many the first language was not English. Officials sometimes resorted to unorthodox methods to communicate with these communities. In Baker Lake, for example, the risk of Cosmos 954 and recovery activities were first explained to the English-speaking children of the community, who were then expected to inform their Inuktitut-speaking parents. ${ }^{61}$ Later, an interpreter from Inuit Tapirisat was asked to facilitate a more organized public meeting. ${ }^{62}$ The Canadian government also provided translations of community information materials, such as posters, in the relevant Indigenous languages of the region. ${ }^{63}$ Communication problems were exacerbated by the fact that the local Indigenous languages did not have words for concepts such as "radiation" or "pollution." These terms had to be translated with words like "poison," which were confusing and did not adequately represent the hazard of contaminants that could not be perceived by human senses. ${ }^{64}$ As one Baker Lake resident complained in a $\mathrm{CBC}$ radio report, the inability to clearly translate nuclear terminology stoked fear and concern in the community: "People are wondering exactly what is going on, what can happen." 65

The attitudes of government officials and the media toward Indigenous people and their land-based lifestyles also contributed to the absence of Indigenous voices in the Operation Morning Light narrative. Indigenous people who travelled, gathered, and hunted within the debris field had reason to be worried about the potential contamination of their traditional territories. Speaking to the territorial legislature, one Northwest Territories member of the legislative assembly highlighted that the uncertainties around threats to fish and wildlife, in particular, sowed concern, even panic in the Cosmos debris-field communities. ${ }^{66}$ Yet the official attitude 
towards undiscovered radiation was that, after permanent settlements and temporary camps had been cleaned up, the chance of someone encountering a highly radioactive particle in thousands of kilometres of wilderness was low. Ingesting a single "average" particle from contaminated snow or country food would equal only the harmless "dose [of radiation] received during an $\mathrm{x}$-ray of the bowels. " ${ }^{7}$ This attitude ignored Indigenous peoples' extensive use of the "wilderness" in question, and their possible exposure to multiple "average" particles through frequent consumption of country food throughout the debris field.

Conflicting interpretations of risk plagued the communications between northern residents and southern bureaucrats or scientists during the recovery. Although government representatives initially downplayed radiation risks, residents of communities south of Great Slave Lake were subsequently warned not to boil snow as a water source, after radioactive dust was found in a snow sample in Fort Resolution. ${ }^{68} \mathrm{~A}$ man from Hay River was exposed to a radioactive particle when he accidentally carried it indoors on his boot. ${ }^{69}$ The ongoing discovery of debris fragments within communities contradicted the official assurances that the probability of encountering radiation was very low. Northerners' concerns about the risk of Cosmos 954 often seemed to be fueled by the uncertainty that this contradiction caused. The man from Hay River reflected decades later that "the real concern wasn't as much radiation as the lack of information that was available about the crash."

A large part of the uncertainty likely had to do with the nature of radiation as a contaminant impossible to detect by observation or physical interaction. Contaminated snow or country food would look and taste safe. A negative reaction to radiation might not occur for hours, days, or even years after a person unknowingly encountered a radioactive fragment. ${ }^{71}$ The uncertainty surrounding potential radiation exposure created a prime opportunity for the Canadian government to step in and exert its authority. Local people had no way of assessing the risk of radiation themselves (for instance, using sensory perception) and so were forced to rely on detection technologies and officially sanctioned assessments of risk. Nevertheless, the lack of absolute certainty in the technological characterizations of radiation risk left some communities with lingering concerns and a distrust of government explanations. In response, officials eventually distributed dosimeters to Royal Canadian Mounted Police (RCMP) outposts in 
selected communities, for use by citizens travelling in the bush who were worried about accidental exposure to radiation. ${ }^{72}$

The primary spaces of official communication about Cosmos 954 radiation were public meetings, which began in the early spring of 1978 . In May, AECB held its first meetings in Lutselk'e and Hay River, communities that had been heavily impacted by radioactive particles. Since the meeting minutes were created by and for the use of government officials, the records of these meetings survive mainly as a one-sided conversation in which officials told local people the correct way to understand the Cosmos 954 incident. ${ }^{73}$ Nevertheless, it is clear that official reassurances during these presentations may not have adequately addressed community uncertainty; among the list of questions at the end of the meetings were:

Is it safe to eat the fish we catch?

Is the water safe to drink?

If the risks are so small, why are you continuing the search? ${ }^{74}$

The scientific information relayed by AECB scientists about these risks was the product of specialist knowledge. Community members who did not have the same specialist knowledge were simply expected to take government statements about risk as truth. Because these statements did not always reflect local perceptions of risk, some community members continued to express the very concerns that public meetings were intended to dispel.

Public meeting minutes also captured northern communities' dissatisfaction with how information surrounding the Cosmos crash and recovery was communicated by the government. For instance, other questions voiced at public meetings included:

Why didn't you come and speak to us before?

Why weren't we given more notice of this meeting?

Why wasn't this meeting held at a better time?

and, revealingly:

Would the Government have done more if the satellite had fallen in the middle of Toronto? ${ }^{75}$ 
The meeting report states only that official analyses of risk were emphasized in the face of community questions and concerns - a strategy that may not have made community members any more willing to trust official statements. ${ }^{76}$ A northern media report describing "tall tales" about the contamination that appeared even before the community clean-ups started speaks volumes about skepticism and distrust towards official explanations:

A source in a trade union ... said that the National Indian Brotherhood and United Steelworkers will be coming out with a press release, asking whether the satellite was intended to finish the job at Yellowknife, N.W.T. started by Giant Yellowknife Mines and Consolidated Mines with arsenic poisoning in the area ...'Maybe they realize the only way to shut us up is to get rid of us all,' the source said. ${ }^{77}$

This quip ironically linked the Cosmos radiation issue to another prominent public health controversy unfolding at the time: the widespread pollution of the Yellowknife region by arsenic emissions from Giant Mine. ${ }^{78}$ At the time of the satellite crash, many people were "not quite sure yet which threat [was] more harmful, Cosmos or arsenic" 79 To these northerners, Operation Morning Light appeared as just one more episode in an ongoing story of southern government apathy towards the contamination of northern landscapes.

Public controversy over radiation from Cosmos faded quickly after the conclusion of Operation Morning Light. Nevertheless, one result of this lingering uncertainty about radiation risks and distrust of government communications has been persistent concern about the presence of radioactive debris in the environment, long after the cleanup. While there seems to be little public memory of Cosmos 954 in southern Canada, careful reading of government publications from the Northwest Territories since then suggests that many northerners remain concerned about their potential exposure to radiation. A 2004 federal pamphlet about environmental contaminants in the Northwest Territories makes reference to the satellite crash. This pamphlet, intended to inform members of the public about the hazards of radionuclides, addresses the possible risk from satellite debris: 
In 1978, the Soviet satellite Cosmos 954 crashed into Great Slave Lake and released nuclear debris. This was a minor addition to radionuclides in the Northwest Territories, and it was not found to be a concern. ${ }^{80}$

A Northwest Territories provincial health report a decade later similarly mentions and dismisses the risks from Cosmos 954, focusing specifically on Fort Resolution:

Debris from the Russian Cosmos 954 ... was speculated to be a potential source of radiological material in the environment ... A 2012 investigation of cancers among residents of Fort Resolution, a community in the vicinity of some of the Cosmos 954 debris, could not establish causal links between radioactive exposure and cancers among local residents. ${ }^{81}$

The fact that the authors of these publications felt it necessary to address Cosmos 954 as a radiation issue - and to reassure the public that it was not a problem-suggests that it was a community concern posed to health officials before. The chief of the Deninu Ku'e First Nation, speaking to the media in 2012, stated that he believed the health report did not take environmental factors such as "radiation from the Soviet satellite" into enough consideration when determining cancer levels in the Fort Resolution area. He believed this to be part of the government's blaming local people for their high rate of cancer, rather than looking seriously for carcinogens in the environment. ${ }^{82}$

Forty years after the incident, concerns about the long-term impacts of Cosmos 954 debris remain both a contributing factor to and a product of a long-standing distrust in this region towards federal government officials. Yet these concerns are, as in the past, typically filtered through official accounts and reports. The written record of Operation Morning Light is largely defined by the very narrow perspective of the political and military leaders in charge of the mission. Looking at this limited documentation alone, it is easy to conclude that the concerns about Cosmos 954 radiation were put to rest with the completion of Operation Morning Light; yet the reason there are few indications of lasting concerns is because of the scarcity of first-hand accounts of how northerners themselves viewed (and 
view) the risk from the radioactive debris. Oral histories with northerners affected by the Cosmos incident and the subsequent recovery operation would contribute to a deeper understanding of these events, as well as local perceptions and experiences of risk and radiation.

More broadly, the neglected yet significant episode of Operation Morning Light illuminates major themes in the historical geographies of northern science and technology, and the politics of environmental knowledge in the region. The Cosmos recovery operation illustrates how official knowledge of northern environments (and environmental hazards) was constituted, both through the particular "regime of perceptibility" that included technologies such as the airplane and the scintillator, and the colonial authority of southern military and scientific experts. These officials' ability to define radiological risks and hazards in technoscientific terms was reinforced by the peculiar geography and materiality of the Cosmos debris itself: contamination eluded direct human perception both at the scale of the field (a huge area where the distribution of contamination was highly uneven) and at the scale of the body, since few people would (like Mordhurst's group) ever encounter debris or learn if they had been in contact with radioactive satellite "fallout." Rather, the legibility of the debris field was established and verified by aerial surveys; the contaminants themselves, by scintillators and distant laboratory tests. The fact that these technologies and strategies proved highly fallible during Operation Morning Light-especially in their deployment under the extreme environmental conditions of a northern winter-did not necessarily derail official narratives that celebrated the operation's achievements in the face of challenging terrain and logistics.

Notably, however, Operation Morning Light struggled to establish the authority of this regime of perceptibility against a backdrop of increasing public knowledge and concern about pollution and shifting relations between Indigenous northerners and the state authorities. Indigenous-state relations were very much in flux during the 1970s and 1980s, as historians Andrew Stuhl and Stephen Bocking point out, as Indigenous people asserted their rights and knowledge in the context of a series of contentious wildlife management and environmental issues. ${ }^{83}$ The Mackenzie Valley Pipeline debates, public health reports about arsenic exposures in Yellowknife, and more generalized concerns about Arctic pollution (and indeed, nuclear fallout) undoubtedly informed the many skeptical reactions of northern 
politicians and Indigenous communities to Operation Morning Light's reassurances about the hazards of exposures and the effectiveness of the cleanup. ${ }^{84}$ Similar issues surrounding uncertainty and the communication of hazards about invisible contaminants and scientific authority would play out again starting in the 1980s, in the controversies over discovery of persistent organic pollutants in northern environments and Indigenous bodies. $^{85}$

Placing Operation Morning Light into the context of these contemporaneous and subsequent pollution controversies helps understand both the dynamics and significance of this otherwise obscure episode. In the end, with respect to Cosmos 954, the traditional authority of experts held sway-in spite of both official and unofficial uncertainties, from technological malfunctions and unreliable risk assessments to conflicting understandings of the land on which the operation played out. The military-led, security-driven nature of the recovery operation and the material qualities of radioactive debris - undetectable to human senses and at times indistinguishable from "background" radiation-seemed to paradoxically reinforce the reliance on expertise while fostering doubt and mistrust. Only in the margins of official accounts, and perhaps the memories of northerners themselves, does the vernacular knowledge and experience of the Cosmos crash linger.

\section{Acknowledgments}

This research was funded through Social Sciences and Humanities Research Council of Canada Grant \#435-2014-0968. The authors would like to thank John Sandlos for his research support and comments on earlier versions of this work. Our understanding of the Cosmos incident and satellite debris benefited from conversations with Lisa Ruth Rand and Josh Lepawsky. We also appreciate

the assistance of archivists at Library and Archives Canada and the Northwest Territories Archives.

\section{Authors}

Ellen Power is a master's student in geography at the University of Toronto.

Arn Keeling is professor of geography at Memorial University in Newfoundland and Labrador. 


\section{Notes}

1. Edmonton Journal report transcript, 30 January 1978, RG60-B Vol. 15 File 20, Atomic Energy Control Board fonds, Library and Archives Canada. [hereafter LAC]

2. Robert Collins, "Kosmos 954: The Spy That Fell From the Sky,"August 1978, RG60-B Vol. 15 File 15, Atomic Energy Control Board [herafter $\mathrm{AECB}]$ fonds, LAC.

3. C.A. Morrison, Voyage into the Unknown (Stittsville, ON: Canada's Wings, Inc, 1984), 133.

4. Department of External Affairs, "Canada and USSR settle claim for damages caused by 'Cosmos 954'," press release, April 2, 1981, RG25 Vol. 22142 File 66-7, Department of External Affairs fonds, LAC.

5. P.Whitney Lackenbauer and Matthew Farish, "The Cold War on Canadian Soil: Militarizing a Northern Environment," Environmental History 12, no. 4 (2007): 920-950; Shelagh Grant, Polar Imperative: A History of Arctic Sovereignty in North America (Toronto: Douglas \& McIntyre, 2010); Klaus Dodds and Mark Nuttall, The Scramble for the Poles (Cambridge, Eng.: Polity Press, 2016).

6. Peter C. Van Wyck, The Highway of the Atom (Montreal and Kingston: McGill- Queen's University Press, 2010); Myra J. Hird, "The DEW Line and Canada's Arctic Waste: Legacy and Futurity," The Northern Review 42 (2016): 23-45.

7. Cosmos 954 has received some attention as an example of the problem of satellite "re-entries," of which there were several in the 1970s and 1980s. See Lisa Parks, "When Satellites Fall: On the Trails of Cosmos 954 and USA 193," in Down to Earth: Satellite Technologies, Industries, and Cultures, eds. Lisa Parks and James Schwoch (New Brunswick, N.J.: Rutgers University Press, 2012), 221-237; Josh Lepawsky, "The Wake of the Anthropocene," Techniques E Culture 55-56 (2016), http://tc.revues.org/7792.

8. Transcript of Global Television news report, January 13, 1979, RG 25 Vol. 16270 File 66-67, Department of External Affairs fonds, LAC.

9. Ken Coates, "The Discovery of the North: Towards a Conceptual Framework for the Study of Northern/Remote Regions," Northern Review 12/13 (1994): 15-43, 15.

10. Shelagh Grant, "Arctic Wilderness-And Other Mythologies," Journal of Canadian Studies 32, no. 2 (1998): 27-42; see also Sherill E. Grace, Canada and the Idea of North (Montreal and Kingston: McGill-Queen's University Press, 2001).

11. Lackenbauer and Farish, "The Cold War on Canadian Soil," 929. 
12. Matthew Farish and P. Whitney Lackenbauer, "High Modernism in the Arctic: Planning Frobisher Bay and Inuvik," Journal of Historical Geography 35 (2009): 517-544, https://doi.org/10.1016/j.jhg.2009.02.002, 520.

13. Matthew Farish, "The Lab and the Land: Overcoming the Arctic in Cold War Alaska," Isis 104, no. 1 (2013): 1-29, 5. See also M. Farish and P.W. Lackenbauer, "Western Electric Turns North: Technicians and the Transformation of the Cold War Arctic," in Ice Blink: Navigating Northern Environmental History, S. Bocking and B. Martin, eds. (Calgary: University of Calgary Press): 261-292.

14. Stephen Bocking, "Situated yet Mobile: Examining the Environmental History of Arctic Ecological Science," in New Natures:Joining Environmental History with Science and Technology Studies, ed. Dolly Jørgenson, Finn Arne Jørgenson, and Sara B. Pritchard (Pittsburgh: University of Pittsburgh Press, 2013): 164-178, 165.

15. Stephen Bocking, "Seeking the Arctic: Science and Perceptions of Northern Canada," Dalhousie Review 90, no. 1 (2010): 61-74, 66.

16. Stephen Bocking, "Science and Spaces in the Northern Environment," Environmental History 12, no. 4 (2007): 867-894, https://www.jstor.org/ stable/25473165, 869; see also Andrew Stuhl, Unfreezing the Arctic: Science, Colonialism, and the Transformation of Inuit Lands (Chicago: University of Chicago Press, 2016); and R.C. Powell, "The Rigours of an Arctic Experiment": The Precarious Authority of Field Practices in the Canadian High Arctic, 1958-1970. Environment and Planning A, 39, no. 8 (2007): 1794-1811.

17. Frank J. Tester and Peter Kulchyski, Tammarniit (Mistakes): Inuit Relocation in the Eastern Arctic, 1939-63 (Vancouver: UBC Press, 1994); P. Clancy, "The Making of Eskimo Policy in Canada, 1952-62: The Life and Times of the Eskimo Affairs Committee," Arctic 40, no. 3 (1987): 191-197; Arn Keeling and Patricia Boulter, "From Igloo to Mine Shaft: Inuit Labour and Memory at the Rankin Inlet Nickel Mine," in Mining and Communities in Northern Canada: History, Politics, and Memory, eds. Arn Keeling and John Sandlos (Calgary: University of Calgary Press, 2015): 35-58.

18. Michelle Murphy, Sick Building Syndrome and the Problem of Uncertainty: Environmental Politics, Technoscience, and Women Workers (Raleigh: Duke University Press), 2006. See also Michelle Murphy, "Chemical Regimes of Living," Environmental History 13, no. 3 (2008): 695-703. Gabrielle Hecht usefully invokes Murphy's "regimes" concept in relation to the colonial production of knowledge about radiological hazards in "Africa and the Nuclear World: Labor, Occupational Health, and the Transnational Production of Uranium," Comparative Studies in Society and History 51, no. 4 (2009): 896-926. 
19. Stephen Bocking, "Toxic Surprises: Contaminants and Knowledge in the Northern Environment," in Ice Blink: Navigating Northern Environmental History, S. Bocking and B. Martin, eds. (Calgary: University of Calgary Press): 421-464.

20. For an overview, see Karen Bickerstaff, "Risk Perception Research: Socio-Cultural Perspectives on the Public Experience of Air Pollution," Environment International, 30, no. 6 (2004): 827-840, and Karen Bickerstaff and Gordon Walker, "The Place(s) of Matter: Matter out of Place: Public Understandings of Air Pollution" Progress in Human Geography 27, no. 1 (2003): 45-67.

21. Martina Tyrrell, "Making Sense of Contaminants: A Case Study of Arviat, Nunavut," Arctic 59, no. 4 (2006): 370-380, https://www.jstor.org/ stable/40512841, 374.

22. Joslyn Cassady, "A Tundra of Sickness: The Uneasy Relationship between Toxic Waste, TEK, and Cultural Survival," Arctic Anthropology 44, no. 1 (2007): 87-97. For similar discussions of Indigenous knowledge of toxicity and hazards in this context, see John D. O'Neil, Brenda Elias, and Annalee Yassi, "Poisoned Food: Cultural Resistance to the Contaminants Discourse in Nunavik," Arctic Anthropology 34, no. 1 (1997): 29-40; Sylvie Poirier and Lorraine Brooke, "Inuit Perceptions of Contaminants and Environmental Knowledge in Salluit, Nunavik," Arctic Anthropology 37, no. 2 (2000): 79-81; Brandy Sistili, Mike Metatawabin, Guy Iannucci, and Leonard J.S. Tsuji, "An Aboriginal Perspective on the Remediation of Mid-Canada Radar Line Sites in the Subarctic: A Partnership Evaluation." Arctic 59, no. 2 (2006): 142-154; Cynthia G. Jardine, Laura Banfield, S. Michelle Driedger, and Christopher M. Furgal, "Risk Communication and Trust in Decision-Maker Action: A Case Study of the Giant Mine Remediation Plan." International Journal of Circumpolar Health 72.SUPPL.1 (2013): 1- 7.

23. Although the satellite is referred to as a "surveillance" satellite in the Operation Morning Light final report, media reports generally refer to it more provocatively as a spy satellite. CFB Edmonton, "Operation Morning Light final report,” November 30, 1978, MG31 G23 Vol. 1 File 1.6, Dick Morrison Fonds, LAC, 14

24. Health Canada, "Radiological and Nuclear Emergencies," April 4, 2014, https://www.canada.ca/en/health-canada/services/health-concerns/ emergencies- disasters/chemical-biological-radiological-nuclear-explosiveevents/radiological-nuclear.html

25. CFB Edmonton, "Final report," G/B-1.

26. Message from Soviet ambassador to Prime Minister P.E. Trudeau, January 26, 1919, R13905-1392-3-E Vol. 75 File 13, Barney Danson Fonds, LAC. 
27. A detailed account of American involvement in Operation Morning Light is found in Jeffrey Richelson, Defusing Armageddon: Inside NEST, America's Secret Nuclear Bomb Squad (New York: W.W. Norton, 2009).

28. Morrison, Voyage, 10-11.

29. CFB Edmonton, "Final report," 2.

30. CFB Edmonton, "Final report," D/1/C-5.

31. Camp Garland/Cosmos Lake Draft Press Release, RG60-B Vol 15 File 15-200-24-4-0, AECB fonds, LAC; CFB Edmonton, "Final report," D/1/D-1.

32. CFB Edmonton, "Final report," 4. The initial search area (encompassing parts of the modern Northwest Territories and Nunavut) eventually expanded to cover northern Saskatchewan and Alberta as radioactive particles dispersed in the atmosphere were discovered in new areas outside the original perimeters of the search zone.

33. CFB Edmonton, "Final report," 30. Search crews initially expected to find the reactor core intact. A "significant percent of the reactor" was found as particulate, but not intact core was discovered.

34. AECB, Atomic Energy Control Board Activities-Cosmos 954 Recovery, July 1978. RG60-B Vol. 15 File 15-200-24-4-0, AECB fonds, LAC.

35. Communities known to lie within the debris field had already been given preliminary searches during Phase $\mathrm{I}$, as had cabins and temporary camps. CFB Edmonton, "Final report," C/B-1. See also R.E. Barrington, "Cosmos 954 Search and Recovery Operation," Advances in Space Research 2,3 (1982): 117-120.

36. Geoffrey Knight, affidavit for Cosmos 954 claim against the Soviet Union, April 30, 1980, RG 25 Vol. 16270 File 66-7, Department of External Affairs fonds, LAC.

37. The background radiation in this area was already higher than the Canadian average. This was partially due to natural mineral deposits in the area, but also to the fallout from the atmospheric nuclear weapons testing of the 1950s and 1960s. F.R. Campbell, Geoffrey B. Knight, J.L. Ricard, and William K. Gummer, "Cosmos 954: The Occurrence and Nature of Recovered Debris and its Hazards," report draft, 8 September 1979, RG25 Vol. 15359 File 66-7, Department of External Affairs fonds, LAC.

38. Barrington, "Cosmos 954 Search and Recovery Operation,"; Health Canada, "Radiological and Nuclear Emergencies."

39. Similarly, in a video posted by the Canadian Nuclear Safety Commission, former AECB officials described the recovery mission as "an adventure" for the normally desk-bound bureaucrats. Canadian Nuclear Safety Commission, “Operation Morning Light,”YouTube video, July 30, 2013. 
40. CFB Edmonton, "Final report," D/1/C-5.

41. Morrison, Voyage, 54.

42. Bill Aikson, "Operation Morning Light", The Sentinel, February 1978, R1526-8566-8-E Vol. 302 File 2, Alastair Gillespie fonds, LAC, 10.

43. Donald Davidson, as quoted in C.A. Morrison, Voyage, 61.

44. CFB Edmonton, "Final report," D/1/C-3.

45. CFB Edmonton, "Final report," D/1/C-4.

46. CFB Edmonton, "Final report," D/1/C-3.

47. Campbell et al, "Cosmos 954: The Occurrence and Nature of Recovered Debris," Appendix C, 1.

48. Aikson, "Operation Morning Light," 13.

49. CFB Edmonton, "Final report,"C/6/A-1.

50. Morrison, Voyage, 37.

51. Morrison, Voyage, 67. In this particular case, the radiation point was eventually located and found to be one of the most highly radioactive fragments recovered by Operation Morning Light. However, many other points of high radiation detected by the aerial surveys turned out to be natural mineral deposits or just false positives.

52. Marionne Cronin, "Northern Visions: Aerial Surveying and the Canadian Mining Industry, 1919-1928," Technology and Culture 48, no. 2 (2007): 304.

53. Stephen Bocking, "A Disciplined Geography: Aviation, Science, and the Cold War in Northern Canada, 1945-1960." Technology and Culture 50, no. 2 (2009): 265-290.

54. CFB Edmonton, "Final report", D/1/C-3.

55. CFB Edmonton, "Final report", C/6/A-5.

56. Morrison, Voyage, 62.

57. Morrison, Voyage, 52; CFB Edmonton, "Final report," G/1-16

58. CFB Edmonton, "Final report," 4.

59. Letter from E.G. Letourneau [Radiation Protection Bureau] to J.D. Leask [Indian and Northern Affairs], March 23, 1978, RG60-B Vol. 15 File 15200-24-4-0, AECB fonds, LAC. The request for Geiger counters was likely mistaking Geiger counters for dosimeters, which had been made available at RCMP outposts throughout the debris field in the AECB's attempt to reassure people that there was a very low chance of coming into contact with radiation while out in the bush.

60. Morrison, Voyage, 51.

61. CFB Edmonton, "Final report," D/1/C-6; Morrison, Voyage, 39.

62. "Satellite explained to Inuit," news report, n.d., RG60-B Vol 15 File 15200-24-4-0, AECB fonds, LAC. 
63. Department of Indian and Northern Affairs, Proposed input regarding public relations information north of 60 before spring break-up, memorandum, February 14, 1978, RG60-B Vol 15 File 15-200-24-4-0, AECB fonds, LAC.

64. Allan Bartley, Transcript of news report draft, January 28, 1978, RG60-B Vol 83-4251 Box 20, AECB fonds, LAC. 31

65. CBC Radio report transcript, 27 January 1978, CBC Archives.

66. CBC Radio report transcript, 3 February 1978, CBC Archives.

67. Geoffrey B. Knight, "Report on Public Meetings held in Communities in Vicinity of Great Slave Lake, NWT, May 24 and 25, 1978," June 6, 1978, RG60-B Vol. 14 File 15-200-24-0-0,AECB fonds, LAC.

68. "Nuclear peril in making tea, village is told," February 28, 1978, RG60-B Vol. 15 File 20, AECB fonds, LAC. See also Nancy Cooper, "Rising radiation fear in Great Slave Lake area fought by federal officials," Globe and Mail, March 4, 1978: 14.

69. Campbell et al, "Cosmos 954: The Occurrence and Nature of Recovered Debris," 67.

70. David Johnson, as quoted in Myles Dolphin, "Kosmos 954 and its unlikely journey to the NWT 35 years ago," Hay River Hub, April 9,2013, http://www.hayriverhub. com/2013/04/kosmos-954-and-its-unlikely-journey-to-the-nwt-35-years-ago/.

71. Olga Kichinskaya, The Politics of Invisibility: Public Knowledge about Radiation Health Effects after Chernobyl (Cambridge, Mass.: MIT Press, 2014); Cassady, "A Tundra of Sickness."

72. Memorandum from William Gummer [AECB] to Terry Jenkin [RCMP], August 2, 1978, RG60-B Vol. 15 File 15-200-24-6-0, AECB fonds, LAC. Dosimeters were made available at RCMP outposts in Fort Resolution, Pine Point, Baker Lake, Lutselk'e, Hay River, and Fort Smith. Some dosimeters were also loaned separately to a group of trappers travelling in the Fort Reliance area. All correspondence about the devices emphasized that the dosimeters were unnecessary for most communities (except in Lutselke, where the most radioactive particles were found), as the likelihood of encountering radiation was very low.

73. The official-public communications throughout Operation Morning Light were a top-down process. The public meetings were structured as a presentation with a question period at the end, as opposed to a round table discussion where each party was given a turn to speak.

74. Knight, "Report on Public meetings."

75. Knight, "Report on Public meetings."

76. Knight, "Report on Public meetings." 
77. Canadian Native News Service, "Satellite tall tales amuse and provoke," February 3, 1978, RG60-B Vol. 14 File 15-200-24-0-0, LAC.

78. John Sandlos and Arn Keeling, "The Giant Mine's Long Shadow: Arsenic Pollution and Native People in Yellowknife, Northwest Territories," in Mining North America: An Environmental History since 1522, eds. John $\mathrm{R}$ Mcneill and George Vrtis (Berkeley: University of California Press, 2017), 280-312.

79. Leo Heaps, Operation Morning Light: Terror in Our Skies, (United States: Paddington Press,1978), 58. Although Heaps' discussion of events is sensationalist at times, Terror in Our Skies remains the only book discussing northerners' reactions to Cosmos 954 beyond the limited military perspective.

80. Government of Canada, Northwest Territories Contaminants Fact Sheets: Radionuclides, Yellowknife:Aboriginal and Northern Affairs, Contamination and Remediation Directorate, 2004, http://www.assembly.gov.nt.ca/sites/ default/files/td_61-175.pdf, 1 .

81. Government of Northwest Territories, Cancer in the Northwest Territories: 2001-2010, Yellowknife: Health and Social Services, 2014, http://www. assembly.gov.nt.ca/sites/default/files/td_61-175.pdf, 26.

82. Paul Bickford, "No red flag: Report finds no environmental cause to cancer increase in Fort Resolution," Northern News Service, September 8, 2012, https://www.nnsl.com/archives/2012-09/sept10_12can.html.

83. Stephen Bocking, "Scientists and Evolving Paradigms of Indigenous Knowledge in Northern Canada," in Walking a Tightrope: Aboriginal People and their Representations, eds. Ute Lischke and David T. McNab (Waterloo: Wilfrid Laurier UniversityPress, 2000): 215-247; Stuhl, Unfreezing the Arctic, Chapter 5.

84. On the connections between pollution concerns and environmental politics in the North in the 1970s, see John Sandlos and Arn Keeling, "Pollution, Local Activism, and the Politics of Development in the Canadian North," RCC Perspectives 2016/4: 25-32.

85. Bocking, "Toxic Surprises"; Marla Cone, Silent Snow: The Slow Poisoning of the Arctic (New York: Grove Press, 2005); D.L. Downie and T. Fenge (eds.), Northern Lights Against POPs: Combatting Toxic Threats in the Arctic (Montreal: McGill-Queen's University Press, 2003). 